\section{National Arthritis Awareness Month — May 2018}

May is National Arthritis Awareness Month. In the United States, 54 million adults have some form of doctor-diagnosed arthritis (1), a number projected to increase to 78 million by 2040.* Approximately two thirds of adults with arthritis have overweight or obesity (1), and only 36\% meet the recommended aerobic physical activity guidelines. ${ }^{\dagger}$

Engaging in physical activity and maintaining a healthy weight can help manage arthritis symptoms. ${ }^{\S}$ Physical activity can reduce arthritis pain, improve function and mood, and delay the onset of disability. Even small amounts of weight loss have been shown to significantly reduce pressure on the joints. Adults who have overweight or obesity and receive weight-loss counseling from a health care provider are approximately four times more likely to attempt to lose weight than are those who do not receive counseling (2). Health care providers can play a valuable role by counseling their patients with arthritis to be physically active, lose weight if they have overweight or obesity, and get self-management education (2,3). A report in this issue found that the percentage of health care providers counseling arthritis patients about weight loss increased significantly from 2002 to 2014 (3).

*https://onlinelibrary.wiley.com/doi/epdf/10.1002/art.39692.

${ }^{\dagger}$ https://www.sciencedirect.com/science/article/pii/S0749379717302076.

$\$$ https://www.cdc.gov/arthritis/basics/management.htm.

\section{References}

1. Barbour KE, Helmick CG, Boring M, Brady TJ. Vital signs: prevalence of doctor-diagnosed arthritis and arthritis-attributable activity limitationUnited States, 2013-2015. MMWR Morb Mortal Wkly Rep 2017;66:246-53. https://doi.org/10.15585/mmwr.mm6609e1

2. Rose SA, Poynter PS, Anderson JW, Noar SM, Conigliaro J. Physician weight loss advice and patient weight loss behavior change: a literature review and meta-analysis of survey data. Int J Obes 2013;37:118-28. https://doi.org/10.1038/ijo.2012.24

3. Guglielmo D, Hootman JM, Murphy LB, et al. Health care provider counseling for weight loss among adults with arthritis and overweight or obesity-United States, 2002-2014. Morb Mortal Wkly Rep 2014;2018:485-90.

\section{Health Care Provider Counseling for Weight Loss Among Adults with Arthritis and Overweight or Obesity - United States, 2002-2014}

\author{
Dana Guglielmo, $\mathrm{MPH}^{1,2}$; Jennifer M. Hootman, $\mathrm{PhD}^{1}$; \\ Louise B. Murphy, $\mathrm{PhD}^{1}$; Michael A. Boring, $\mathrm{MS}^{1}$; \\ Kristina A. Theis, $\mathrm{PhD}^{1}$; Brook Belay, $\mathrm{MD}^{3}$; Kamil E. Barbour, $\mathrm{PhD}^{1}$; \\ Miriam G. Cisternas, MA ${ }^{1}$; Charles G. Helmick, MD $^{1}$
}

In the United States, 54.4 million adults report having doctor-diagnosed arthritis (1). Among adults with arthritis, $32.7 \%$ and $38.1 \%$ also have overweight and obesity, respectively (1), with obesity being more prevalent among persons with arthritis than among those who do not have arthritis (2). Furthermore, severe joint pain among adults with arthritis in 2014 was reported by $23.5 \%$ of adults with overweight and $31.7 \%$ of adults with obesity (3). The American College of Rheumatology recommends weight loss for adults with hip or knee osteoarthritis and overweight or obesity,* which can improve function and mobility while reducing pain and disability $(4,5)$. The Healthy People 2020

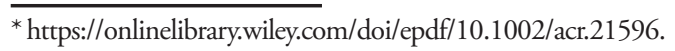

\section{INSIDE}

491 Progress Toward Measles Elimination — Western Pacific Region, 2013-2017

496 Vital Signs:Trends in Reported Vectorborne Disease Cases — United States and Territories, 2004-2016

502 Notes from the Field: Salmonella Oranienburg Infection Linked to Consumption of Rattlesnake Pills Kansas and Texas, 2017

504 Notes from the Field: Increase in Hepatitis A Virus Infections - Marshall Islands, 2016-2017

506 QuickStats

Continuing Education examination available at https://www.cdc.gov/mmwr/cme/conted_info.html\#weekly.

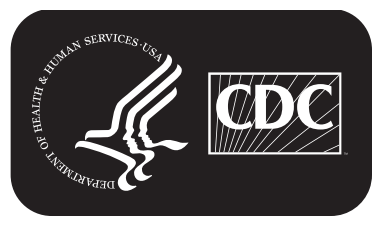

